\title{
PROBABILITIES OF PHYSICAL LINK BETWEEN THE COMPONENTS OF THE SELECTED MULTIPLE SYSTEMS FROM WDS CATALOG
}

\author{
N.V. Maigurova, Yu.I. Protsyuk \\ Research Institute "Mykolaiv Astronomical Observatory", Ukraine, \\ nadija@nao.nikolaev.ua,yuri@nao.nikolaev.ua
}

\begin{abstract}
Astrometric CCD observations of visual components of double and multiple stars were performed using the RI MAO Axial Meridian Circle (AMC) with new Apogee Alta AI-F8300 CCD camera mounted at the telescope in 2018. Observations were carried out automatically in driftscan mode using a standard R filter. Objects for observational program were selected from the Washington Double Star Catalog (WDS). During the 23 nights, 983 observations of 579 double and multiple systems from the WDS catalog were obtained. Astrometric reductions of the observations showed high accuracy, with an average error of one position about 0.1 " in right ascension and declination for stars up to $16^{\mathrm{mag}}$, which were observed more than 3 times.
\end{abstract}

The purpose of our study was to measure the parameters of the mutual configuration of pairs from the original images and to draw some conclusions about the physical connection of the components in the selected systems. The measurement array that will be sent to the WDS database includes values of positional angle, angular separation, stellar magnitude difference, and epoch of the observation. A detailed analysis of the pairs of stars in the selected 5 systems to clarify their composition and the nature of the link between them was made. Positional data from the Hipparcos, Tycho2, UCAC4, Gaia DR2, and Pan-STARRS (PS1) catalogs were used as sources of additional information about the investigated stars. The search for possible invisible stars in the selected systems was performed using the statistical Wielen method, based on the analysis of the differences of instantaneous and long-term averaged proper motions of the stars. The proper motions of the space Gaia DR2 catalog were considered to be instantaneous, the long-term averaged proper motions were used from Tycho-2 and UCAC4 catalogs. Obtained values of the statistical parameter in some cases indicate a high probability of existence of invisible close components in the studied systems. Detailed comments of the results for each of the selected systems are provided.

Keywords: Double and multiple stars, binary stars, CCD observations, astrometric positions, common proper motions.

АНОТАЦІЯ. Астрометричні ПЗЗ-спостереження візуальних компонентів подвійних та кратних зірок виконувались за допомогою Аксіального меридіанного круга НДІ МАО з новою ПЗ3-камерою Apogee Alta AIF8300, що була встановлена на телескопі у 2018 році. Спостереження проводились у автоматичному режимі методом переносу заряду з використанням стандартного фільтру R. Об'єкти для програми спостережень було обрано 3 каталогу подвійних зірок Вашингтонської обсерваторії (WDS). Протягом 23 ночей отримано 983 спостереження 579 подвійних та кратних систем 3 каталогу WDS. Астрометричні редукції спостережень показали досить високу точність, середня похибка одного положення складає близько 0.1" для прямого піднесення та схилення для зірок до 16 зоряної величини, що спостерігались більше 3 разів.

Метою нашого дослідження було вимірювання параметрів взаємної конфігурації пар з оригінальних зображень та отримання певних висновків щодо фізичного зв'язку компонентів у обраних системах. Массив вимірювань, що буде надіслано до бази даних WDS, включає значення позиційного кута, кутового розділення, різниці зоряних величин та епоху спостережень. Виконано детальний аналіз пар зірок, що входять до обраних 5 систем для уточнення їх складу та природи зв'язку між ними. Позиційні дані 3 каталогів Hipparcos, Tycho2, UCAC4, Gaia DR2 та PanSTARRS (PS1) використовувались як джерела додаткової інформації про зірки, що досліджувались. Виконано пошук можливих невидимих зірок у обраних системах 3 застосуванням статистичного методу Вілена, що базується на аналізі різниць миттєвих та усереднених довгострокових власних рухів зірок. Власні рухи каталогу Gaia DR2 було розглянуто як миттєві, в якості довгострокових власних рухів залучено дані каталогів Tусhо-2 та UCAC4. Отримані значення статистичного параметру в деяких випадках вказують на високу ймовірність існування невидимих близьких компонент в досліджуваних системах. Представлені детальні коментарі до результатів для кожної з розглянутих систем.

Ключові слова: подвійні та кратні зоряні системи, фізично зв'язані подвійні зорі, ПЗ3-спостереження, астрометричні положення, власні рухи.

\section{Introduction}

Binary and multiple stars are unique objects for direct determining physical characteristic of stars (primarily mass), through a combined analysis of photometric, astrometric, and spectroscopic data. This paper has deal mainly with positional observations to determine the separation between components of star and the position angle at the observational epoch in order to supplement the observation 
history. These parameters are also value information for clarify the nature of the link between the system components and in case of the existence of a gravitational link between stars, these data can be used to obtain elements of the orbits of the binary system. The principal database of double and multiply stars is Washington Double Star Catalog (WDS) (Mason et al., 2001) maintained by the United States Naval Observatory. The WDS lists 149730 (as the autumn, 2019) of resolved stellar systems with two and more components. But the main question for researchers is whether the pair that they see in their telescopes is gravitationally connected to each other, or this is the result of the random arrangement of stars on the celestial sphere, which are very far from each other in reality. Only a small part of the WDS records have enough observations to detect the orbital motion of stars around each other. The Sixth Orbit Catalog (ORB6) included only 2,662 orbits of 2,558 systems as of 25 April 2016 (https://www.usno.navy.mil/USNO/astrometry/optical-IR$\mathrm{prod} / \mathrm{wds} / \mathrm{orb6}$ ). Therefore ground-based observa-tions such objects do not lose their value despite the many existing modern astrometric dense catalogs.

\section{Telescope and Observational Program}

The regular observations of binary and multiply stars at RI MAO have been carried out at two telescopes: Axial Meridian Circle (2013 - 2015, 2018-2019) (Bodryagin et al, 2015) and KT-50 of Mobitel complex (2014-2019), (Bodryagin et al, 2016;2017, Maigurova et al.,2018) . For several years, we did not observe double stars at AMC for technical reasons. With the installation of a new camera in 2018, observations were resumed. The all characteristics of updated instrumental system are given at Tab. 1.

The observations of visual double and multiply stars from WDS catalog were performed during 2018/05 2018/10 in drift scan mode. During 23 nights we obtained 983 observations for 579 WDS system in R photometric band. Mean epoch of our observations is 2018.5 and mean time difference between last observation in WDS database and our observations is 6 years, but $10 \%$ stars have the differences in range from 15 up to 100 years. So this indicates that our data can be useful for extend the arc length of the observed orbit of binary system. Distribution of observations over celestial sphere is shown in Fig. 1.

Table 1: The characteristics of AMC instrumental system

\begin{tabular}{|l|l|}
\hline Telescope & $\begin{array}{l}\text { AMC RI “MAO” } \\
\text { (Mykolaiv, Ukraine) }\end{array}$ \\
\hline$\lambda, \varphi\left(^{\circ}\right)$ & $31.9701,46.9721$ \\
\hline Type & Refractor \\
\hline $\mathrm{D}(\mathrm{mm})$ & 180 \\
\hline $\mathrm{F}(\mathrm{mm})$ & 2500 \\
\hline CCD & Apogee Alta AI-F8300 \\
\hline Size $($ pix $)$ & 3326 x 2504 \\
\hline Pixels,$\left(\mu \mathrm{m}^{2}\right)$ & $5.4 \times 5.4$ \\
\hline Scale $(\operatorname{arcsec} /$ pix $)$ & $0.45^{\prime \prime} / \mathrm{px}$ \\
\hline FOV $(\operatorname{arcmin})$ & $25^{\prime} \times 25^{\prime}$ \\
\hline Exposure $\left(\mathrm{dec}=0^{\circ}, \mathrm{s}\right)$ & 100 \\
\hline Filter Weal & FL-CFW-2-7 \\
\hline Filters & AN-R-50R, AN-V-50R AN-B-50R \\
\hline
\end{tabular}

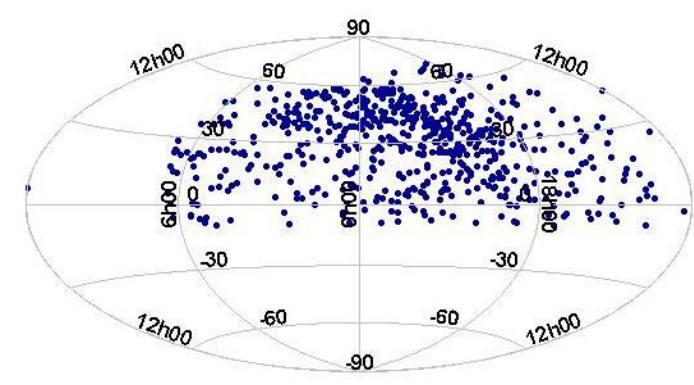

Figure 1: Distribution of the observations over celestial sphere.

\section{Measurements}

We carried out all astrometric reductions with the "Astrometrica" software (http://www.astrometrica.at). The root mean square errors of the differences $(\mathrm{O}-\mathrm{C})$, where $\mathrm{O}$ - obtained equatorial coordinates, C - Gaia DR2 equatorial coordinates, of the stars up to $16^{\mathrm{mag}}$ in R-band (with $\mathrm{N}_{\mathrm{obs}}$ $>=3$ ) were $\mathbf{0 . 1 2}$ " in right ascension and $\mathbf{0 . 1 1}$ " in declination. It should be noted that here we used astrometric reductions mainly for confident identification of program objects and obtaining exact values of the image orientation angle regarding the celestial equator for further measurements of the parameters of the mutual configuration of the investigated components. The measurements of position angles and separations were made with REDUC software (http://www.astrosurf.com/ hfosaf/reduc), according standard processing procedure. The final array of measurements includes values of positional angle, separation, difference magnitude, magnitude difference, number of observations for all pairs of the WDS system and known notes about link. The example of table with measurement results for selected pairs presented in Tab.2. Column 3, 4, 5 with adding exact observational epoch will send to WDS database. Information from Stelle Doppie web-resource (https://www.stelledoppie.it) about nature of link between components based on their proper motions, is given at last column in Tab.2, where $G$ means gravitationally bounded double, $\mathrm{U}$ - nature of this double is uncertain, $\mathrm{N}$ - optical double.

Table 2: Measurements of the selected WDS systems

\begin{tabular}{|l|l|l|l|l|l|l|}
\hline WDS & Pair & PA, $^{\circ}$ & Sep, & $\begin{array}{l}\text { dMag, } \\
\text { mag }\end{array}$ & N & Link \\
\hline $00318+3658$ & AB* & - & - & - & 23 & G \\
\cline { 2 - 7 } & AC & 165.4 & 31.5 & 2.9 & 13 & U \\
\cline { 2 - 7 } & AD & 174.4 & 43.6 & 1.3 & 16 & N \\
\cline { 2 - 7 } & BD* & - & - & - & 11 & N \\
\cline { 2 - 7 } & CD & 195.7 & 13.5 & 1.6 & 12 & N \\
\hline $02157+1046$ & AB & 236.2 & 14.5 & 0.4 & 34 & G \\
\cline { 2 - 7 } & AC & 275.3 & 71.9 & 2.4 & 16 & U \\
\cline { 2 - 7 } & AE & 5.1 & 174.6 & 1.1 & 14 & U \\
\cline { 2 - 7 } & BE & 8.6 & 184.0 & 0.7 & 13 & U \\
\hline $03325+5420$ & AB & 1.2 & 20.5 & 2.1 & 7 & U \\
\hline & AC & 319.9 & 26.6 & 2.5 & 7 & N \\
\hline & BC & 269.7 & 17.4 & 0.3 & 7 & N \\
\hline $05519+4844$ & AB & 316.4 & 9.0 & 1.2 & 17 & G \\
\hline & AD & 259.8 & 116.7 & 0 & 16 & G \\
\hline & BC & 307.7 & 32.9 & 1.9 & 9 & U \\
\hline $22105-0251$ & AB & 4.0 & 51.1 & 1.2 & 8 & U \\
\hline & AC & 94.8 & 51.1 & 0.5 & 9 & U \\
\hline & BC & 139.4 & 72.6 & 0.8 & 8 & U \\
\hline
\end{tabular}

\footnotetext{
*- not measured
} 


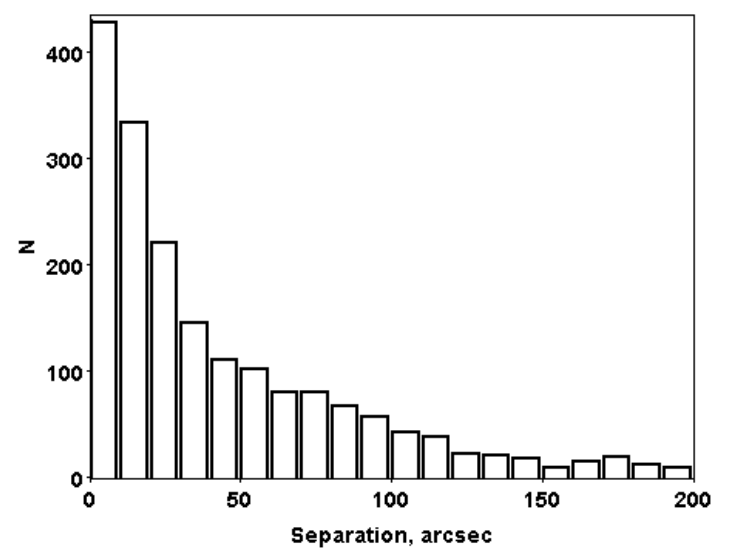

Figure 2: Distribution of the angular separation for all pairs of our observations.

There are several reasons why direct measurements of the mutual configuration parameters from astrometric CCD observations are impossible. The main star is often too bright and its image is oversaturated, some of the components in the systems under study had too weak magnitudes for the instrument. In general direct measurements were possible only for pairs with separation which at least exceeds 3 FWHM (in case of the AMC the mean FWHM is about 3"). The distribution of the angular separation for our observations is presented in the Fig. 2 .

As could be seen from the Fig.2, significant part of components is not available for direct measurements. In our opinion a large number of known pairs with a low angular resolution suggest that some stars from double and multiple systems may have invisible undiscovered components. Statistical method for detecting and searching of the invisible components of stars was proposed Wielen (Wielen, et al., 1999) back in the 90s. These stars are called delta- $\mu$ binaries. The method is based on the comparison of proper motions of stars obtained for various time intervals and the assumption that the movement of its photo center for a sufficiently long period of time is not linear but wavy for a binary system with an invisible companion. If the normal practice of obtaining proper motions by ground based observations is based on observations with the difference of epochs of 20-50 years or more, the proper motions obtained with the Hipparcos and Gaia DR2 space catalogs can be considered within this methodology as instantaneous. For a long time, the main limitation of this method was the insufficient accuracy of long-term averaged proper motions. For a now there are some catalogs with accuracy proper motions like Tycho2 (Hog et al., 2000) and UCAC4 (Zacharias et al., 2013) catalogs. In addition the appearance of high-precision space catalog Gaia DR2 made possible to calculate high precision long term averaged proper motions for Hipparcos stars on 24 years difference epoch. Search secondary object for nearby stars based on anomaly between the long-term proper motion vector and the Gaia DR2 (or Hipparcos) measurements was performed by Kervella (Kervella et al., 2019). These calculations are in the Strasbourg database and may be available for wide use. Perhaps this is the most accurate averaged proper motions, but unfortunately only for Hipparcos catalog stars. In this study we used proper motions and their errors from Tycho 2 catalog primarily and then UCAC4. The Gaia DR2 parallax, proper motions, averaged long term proper motions from UCAC4 and Tycho 2 catalogs and their errors are presented in Tab.3 for all stars that included in selected WDS system. The last column of Tab. 3 contains value F-criteria calculated as :

$$
F=\sqrt{\left(\frac{\Delta \mu_{-} R A}{\varepsilon_{-} \Delta \mu_{-} R A}\right)^{2}+\left(\frac{\Delta \mu_{-} D E C}{\varepsilon_{-} \Delta \mu_{-} D E C}\right)^{2}}
$$

where $\Delta \mu_{R A}, \Delta \mu_{R A}$ are corresponding differences between long term and instantaneous proper motions, while $\varepsilon_{\Delta \mu_{R A}}, \varepsilon_{\Delta \mu_{D E C}}$ are errors of their determination.

Stars with a value criteria $F>2.49$ were considered as $\Delta \mu$-double candidates with a $95 \%$ probability.

\subsection{WDS $00318+3658$}

There are 5 entries for 4 stars of the system in WDS catalog. The separation between A and B component is 6.8" and this is reason we can't measure B component from our images. The main star is 2509 Hipparcos. The Gaia DR2 parallaxes confirm that $\mathrm{A}$ and $\mathrm{B}$ stars are gravitationally bounded pair while C component doesn't bound with them. C component have significantly different parallaxes and radial velocity. $F-$ values for stars of the WDS $00318+3658$ system doesn't show possible invisible companion in them.

\subsection{WDS $02157+1046$}

The system includes 4 entries. Common proper motions and parallaxes indicate that pair $\mathrm{AB}$ is a physical binary system only. Despite star C is included in Tycho Double Star Catalogue (Fabricius et al., 2002) proper motions and parallax star C significantly different, which makes it unlikely that star $\mathrm{C}$ belongs to the $\mathrm{AB}$ system. The belonging of the star $\mathrm{E}$ to the system remains uncertain since there are no proper motions and parallax data for the star in the Gaia DR2 catalog.

\subsection{WDS $03325+5420$}

Apparently there are no physically connected pairs in this system; large value $F$ for star $\mathrm{C}$ could indicate the presence of invisible satellite. There is a weak object at a distance of 0.2 " from star C in the Gaia DR2 catalog. Unfortunately with no information about parallax and proper motions of this star and bad accuracy averaged proper motions of the star $\mathrm{C}$, this this conclusion remains uncertain.

\subsection{WDS $05519+4844$}

There are 4 stars and 3 entries for this system in WDS catalog. Stars A, B, D form triple system, star C is not included there.

\subsection{WDS 22105-0251+5420}

According Gaia DR2 data star B and star C could be physical pair, but they have different radial velocities. Star B also have large value $F$ parameter that could be point on presence invisible satellite near to this star. 
Table 3: Measurements of the selected WDS systems

\begin{tabular}{|c|c|c|c|c|c|c|c|c|c|c|c|c|}
\hline & \multicolumn{6}{|c|}{ Gaia DR2 } & \multicolumn{6}{|c|}{ Long-term data } \\
\hline & $\begin{array}{l}\text { Plx, } \\
\text { mas }\end{array}$ & $\begin{array}{c}\varepsilon, \\
\text { mas }\end{array}$ & $\begin{array}{l}\text { PMRA, } \\
\text { mas/year }\end{array}$ & $\begin{array}{c}\varepsilon, \\
\text { mas/year }\end{array}$ & $\begin{array}{l}\text { PMDE, } \\
\text { mas/year }\end{array}$ & $\begin{array}{c}\varepsilon, \\
\text { mas/year }\end{array}$ & $\begin{array}{l}\text { PMRA, } \\
\text { mas/year }\end{array}$ & $\begin{array}{c}\varepsilon, \\
\text { mas/year }\end{array}$ & $\begin{array}{l}\text { PMDE, } \\
\text { mas/year }\end{array}$ & $\begin{array}{c}\varepsilon, \\
\text { mas/year }\end{array}$ & Source & $\mathbf{F}$ \\
\hline \multicolumn{13}{|l|}{$00318+3658$} \\
\hline $\mathrm{A}$ & 5.02 & 0.06 & -15.0 & 0.1 & 4.4 & 0.1 & $\begin{array}{l}-15.8 \\
\end{array}$ & 2.2 & 8.0 & 2.1 & Tycho2 & 1.73 \\
\hline B & 5.00 & 0.05 & -14.8 & 0.1 & 4.0 & 0.1 & -14.9 & 2.5 & 4.2 & 2.5 & UCAC4 & 0.08 \\
\hline $\mathrm{C}$ & 1.03 & 0.10 & -16.0 & 0.1 & -6.9 & 0.2 & -10.3 & 3.0 & -3.0 & 3.1 & UCAC4 & 2.27 \\
\hline $\mathrm{D}$ & 2.37 & 0.06 & 19.6 & 0.1 & -1.6 & 0.2 & 17.5 & 3.3 & -5.2 & 3.2 & Tycho2 & 1.28 \\
\hline \multicolumn{13}{|l|}{$02157+1046$} \\
\hline $\bar{A}$ & 9.89 & 0.04 & 59.6 & 0.1 & -65.6 & 0.1 & 58.9 & 0.9 & -66.5 & 1.0 & UCAC4 & 1.23 \\
\hline $\mathrm{B}$ & 9.91 & 0.04 & 61.1 & 0.1 & $\begin{array}{l}-70.9 \\
\end{array}$ & 0.1 & 60.2 & 1.0 & -71.4 & 1.4 & UCAC4 & 0.95 \\
\hline $\mathrm{C}$ & 2.30 & 0.05 & 32.8 & 0.1 & -14.8 & 0.1 & 31.3 & 1.7 & \begin{tabular}{|c|}
-14.1 \\
\end{tabular} & 1.3 & UCAC4 & 1.03 \\
\hline $\mathrm{E}^{*}$ & 5.30 & 0.25 & 53.3 & 3.6 & -31.3 & 1.2 & 54.7 & 0.7 & -30.0 & 1.7 & UCAC4 & 0.75 \\
\hline \multicolumn{13}{|l|}{$03325+5420$} \\
\hline A & 2.25 & 0.04 & 15.7 & 0.1 & -5.0 & 0.1 & 13.1 & 1.9 & -4.7 & 1.9 & Tycho2 & 1.37 \\
\hline $\mathrm{B}$ & 0.46 & 0.21 & -0.6 & 0.4 & -0.1 & 0.4 & 6.1 & 4.9 & 3.0 & 1.9 & UCAC4 & 2.10 \\
\hline $\mathrm{C}$ & 0.96 & 0.02 & 1.3 & 0.1 & -3.1 & 0.1 & -7.7 & 9.2 & 1.6 & 2.1 & UCAC4 & 2.44 \\
\hline \multicolumn{13}{|l|}{$05519+4844$} \\
\hline $\mathrm{A}$ & 1.45 & 0.06 & 2.0 & 0.1 & -6.4 & 0.1 & 3.8 & 1.7 & -7.8 & 1.7 & Tycho2 & 1.34 \\
\hline $\mathrm{B}$ & 1.38 & 0.19 & 3.3 & 0.3 & -6.7 & 0.2 & 3.3 & 1.6 & -9.6 & 1.5 & Tycho2 & 1.91 \\
\hline $\mathrm{C}$ & 2.06 & 0.04 & 18.2 & 0.1 & -42.5 & 0.1 & 16.6 & 61.4 & -39.6 & 2.0 & UCAC4 & 1.45 \\
\hline $\bar{D}$ & 1.65 & 0.05 & 6.4 & 0.1 & -7 & 0.1 & 6.6 & 1.3 & -7.0 & 1.3 & Tycho2 & 0.15 \\
\hline \multicolumn{13}{|l|}{$22105-0251$} \\
\hline $\mathrm{A}$ & 7.65 & 0.17 & 68.4 & 0.2 & 6.6 & 0.2 & 71.0 & 2.3 & 5.6 & 2.5 & Tycho2 & 1.19 \\
\hline $\mathrm{B}$ & 0.43 & 0.08 & 4.3 & 0.1 & $\begin{array}{l}-5.8 \\
\end{array}$ & 0.1 & 15.0 & 1.8 & -3.4 & 2.5 & UCAC4 & 6.71 \\
\hline $\mathrm{C}$ & 0.62 & 0.10 & 4.7 & 0.1 & -4.5 & 0.1 & 4.4 & 1.2 & -2.8 & 2.5 & UCAC4 & 0.72 \\
\hline
\end{tabular}

\section{Conclusion}

Star masses are the key for understanding of the stars and star systems (their birth, evolution and death), therefore regular observations of binary and multiple stars are very important for enlargement observed arc orbit and small ground-based telescopes can be used for this purpose. New positional data (separation, positional angle) were obtained from CCD observations with AMC of RI MAO. Observational data will be sent to the coordinators of the WDS catalog and include to the general database.

The question of the reliability of the existence of gravitational link between the system component is the main one in the study of binary and multiple systems. Combination of the precise astrometric data from Gaia DR2 catalog with similar data from modern astrometric catalogs (Hipparcos and Tycho, Tycho-2, UCAC2, 4) with other observational epoch allow us to clarify the composition of known systems. The search for probable nearby invisible component in multiple systems using the method checking differences between instantaneous Gaia DR2 proper motions and averaged long- term proper motions was conducted.

Acknowledgements. The authors are grateful to colleagues who have taken part in observations of WDS double and multiple systems: M. Kulichenko, M. Kaliuzhnyi, V. Kryuchkovskyi, D. Bodryagin, F. Bushuev, I.Osadchuk.

\section{References}

Astromerica, [on-line resourse].

Available at: http://www.astrometrica.at

Bodragin D.V., Bondarchuk, L.Ye., Maigurova N.V.: 2017, Sci. Innov., 46.

Bodragin D. V., $\quad$ Bondarchuk, L. Ye.;Maigurova, N. V.: 2016, JDSO, 320.

Bodryagin D., Maigurova N.: 2015, Odessa Astron. Publ., 28, 163.

Fabricius C., Høg E., Makarov V.V.: 2002, A\&A, 384, 180.

Gaia Collaboration: 2018, $A \& A, \mathbf{6 1 6}, 1$.

Hog E., Fabricius C., Makarov V.V. et.al.: 2000, A\&A, 355, L27.

Kervella P., Arenou F., Mignard F. et.al: 2019, A\&A, 623, 72.

Maigurova N.V., Protsyuk Yu.I., Bondarchuk L.E.: 2018, Odessa Astron. Publ., 31, 220.

Mason B.D., Wycoff G.L., Hartkopf W.I.: 2001, AJ, 122, 3466.

REDUC software, [on-line resourse].

Available at: http://www.astrosurf.com/hfosaf/reduc

Sixth Catalog of Orbits of Visual Binary Stars, [on-line resourse]. Available at: https://www.usno.navy.mil/ USNO/astrometry/optical-IR-prod/wds/orb6

Stelle Doppie [on-line resourse].

Available at: (https://www.stelledoppie.it)

Zacharias N., Finch C.T., Girard T.M. et al.: 2013, AJ, 145, 44. Wielen R., Dettbarn C., Jahreiss H. et al.: 1999, A\&A, 346, 675. 